\title{
THE ROLE OF SUPPLY CHAIN COLLABORATION ON SUSTAINABLE SUPPLY CHAIN MANAGEMENT PERFORMANCE
}

\section{DOI: 10.17261/Pressacademia.2015312952}

\author{
Huseyin Ince', Andac Sahinbey Ozkan² \\ 'Gebze Technical University. h.ince@gyte.edu.tr \\ ${ }^{2}$ Gebze Technical University. asahinbey@gyte.edu.tr
}

\section{Keywords \\ Supply chain management, sustainable supply chain management, collaboration.}

JEL Classification

M11,D21,L11

\begin{abstract}
Sustainable supply chain management and collaboration have taken big attention from academicians and practitioners. The extensive literature review is conducted to analyse the relationship between Sustainable Supply Chain Management and collaboration and its effects on performance of SSCM dimensions. Then, a framework is proposed to explain the relationship between sustainable supply chain management and collaboration. For further studies the proposed framework should be tested empirically.
\end{abstract}

\section{INTRODUCTION}

The focus on managing the sustainability of manufacturing operations has increased in recent decades. Pressures from external and internal agents; such as environmental laws, environmental regulations, stakeholders demand for sustainable goods and services, interest groups and reducing cost with improving quality, manage risks and acquiring environmental and social image to get the advantage initiatives to competitors, compel organizations to take appropriate steps (Alblas et al., 2014).

Due to increasing interest of sustainable supply chain management (SSCM), Seuring and Muller (2008) made a comprehensive literature review (cf. Beske \& Seuring, 2014).

Sharma and Henriques (2005) state that the increasing demand from multiple parties has forced companies to start the integration of SSCM to increase their related performance (cf. Gualandris, Golini, Kalchschmidt, 2014). Several researchers have made important contributions to analyze the connection between environment of corporations and their operations like strategy, finance, product design, customer relations. It is very critical to move forward all issues in a systematic way to intersect sustainability, environment and supply chain management (Linton et al., 2007). In their study Hudnurkar et al., (2014) suggested that supply chain collaboration and increased supply chain performance association should be developed and tested empirically.

Having efficient supply chain and being able to react the dynamic market conditions, firms feel to accomplish greater supply chain collaboration to reinforce the resources and information of related parties. Supply chain collaboration plans and maintains activities 
together with the supply chain members to execute the operations. This can provide benefits and advantages such as sharing risks, reducing transaction costs, enhancing the productivity and competitive advantage over time to the partners (Cao and Zhang, 2011). Gottfredson et al., (2005) discuss the significance of collaboration by supporting development of core competencies and strategic capabilities within the corporation and outsourcing their other operations. Vargo and Lusch (2004) emphasize the importance of collaboration to a corporation's business strategy and a source of competitive benefits with all stakeholders and even competition in the market to cooperate for solutions (cf. Zacharia, Nix, Lusch, 2011).

The objective of the paper is to investigate the SSCM and collaboration, and to develop a conceptual model based on the relationship between supply chain collaboration and SSCM performance.

In the following sections, a comprehensive review of the literature on supply chain management (SCM), sustainability and SSCM, supply chain collaboration are presented. The last sections include a conceptual model explaining the relationship between supply chain collaboration and SSCM performance, conclusion and further researches.

\section{LITERATURE SURVEY}

\subsection{Supply Chain Management}

According to Mentzer (2001) supply chain management refers to the systematic, strategic alignment of the conventional functions and the approaches across these business functions within specific firms and through the supply chain to improve the performance of the individual firms in the long term and the supply chain as entirely. Supply chain management is the efficient execution of planning, maintaining and controlling activities for the supply chain members to meet the objectives. Achieving this design or reconfiguration becomes very important in terms of the decision of the feasibility of production plants and distribution centers (Varsei et al., 2014). Supply chain management is also considered as maximization of the supply chain profitability with controlling of the supply chain operations, resources, information and funds together with satisfaction of the customers (Hassini et al., 2012).

Varma (2006) emphasizes the creation of complex supply chains as the trend of Globalization and recent economic growth. Gold (2009) explains key issues of design, organization, interactions, competences, capabilities and management in the supply chains. Firms fulfill competitive advantage and responsible behavior at all stages of the supply chain with SCM. Preuss (2005) has a different view and explains SCM as "a corporate function of increasing economic importance, but one that is not pulling its weight in environmental protection".

\subsection{Sustainable Supply Chain Management}

Sustainability is a complex concept which has different and wide operationalization. Faber et al. (2005) found variety sustainability definitions in literature reaching through many years of research. The idea of sustainability was first mentioned by Schumacher as early as 1972, as "permanence", where "nothing makes economic sense unless its continuance for 
a long time can be projected without running into absurdities" (Ashby et al., 2012). World Commission on Environment and Development (WCED) defines the sustainability as a progress that fulfills the current needs without risking the ability of fulfilling future generations' needs (WCED, 1987). Despite the macroeconomic description of WCED, sustainability incorporates social, environmental and economic problems.

With Elkington's (1998) conception of triple bottom line is down to a micro-economic level that explains economic, environmental and social issues (cf. Gimenez, Sierra, Rodon, 2012). Increasing pressures originating from both regulations and public perception, and the seeking of sustainable development is a compulsory (Fabbe-Costes et al., 2014). Linton et al. (2007) argues that the supply chain considers the product from cradle to grave of the products. Therefore, concentrating on supply chains is a step towards the broader integration and development of sustainability. Economic sustainability refers to production or manufacturing costs. Environmental sustainability refers to reducing the waste, pollution, energy usage, emissions, consumption of hazardous/harmful/toxic materials, the frequency of environmental incidents, etc. Social sustainability refers both internal (i.e., employees) and external parties that indicate fair potentials, encourage differences, promote independency within whole supply chains, provide life quality and democratic environment and trustable organization structures (Gimenez et al., 2012). Teuteberg and Wittstruck (2010) proposed the "House of Sustainable Supply Chain" (Fig. 1), the three dimensions of the Triple Bottom Line which are viewed as the key pillars (cf. Zailani, Jeyaraman, Vengadasan, Premkumar, 2012).

Figure 1: House of SSCM (Adopted from Teuteberg and Wittstruck, 2010)

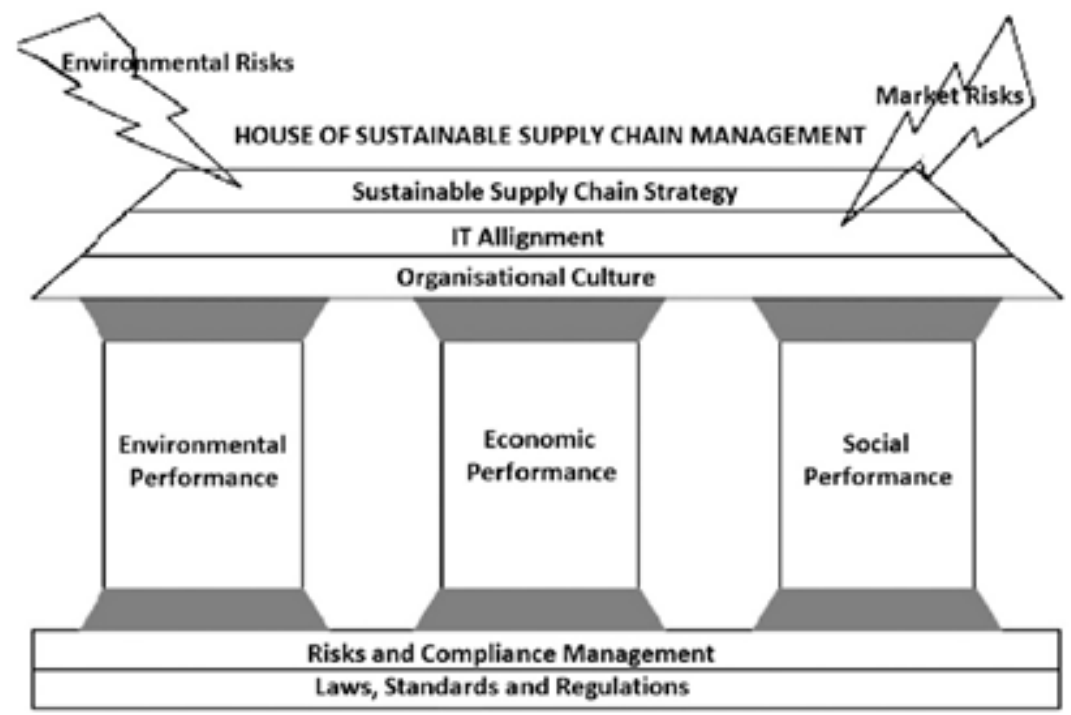

SSCM is seen as an emergent field of SCM (Ashby et al., 2012). Seuring and Müller (2008) define SSCM as [. . .] the management of material, information and capital flows as well as cooperation among companies along the supply chain while taking goals from all three dimensions of sustainable development, i.e. economic, environmental and social, into 
accounts which are derived from customer and stakeholder requirements. The SSCM composes with bilateral movement of substantial and intangible sources and three dimensions of sustainability which apply the evaluation of all stakeholders in an organization and environmental obscureness for the corporations (Beske, 2012). In SSCM, social performance (i.e., non-environmental performance) that emphasizes the consumers, stakeholders and employees, etc., economic performance indicates supply chain financial lucrativeness, and the environmental performance means to execution as regulation side (Ji et al., 2014). According to Gupta and Desai (2011), SSCM is a set of managerial practices that include environmental impact as a compulsory and consult the supply chain process based on value chain of commodity and multi-dimensional prospect that powers the product life cycle.

Leenders et al., (2006) states that a sustainable supply chain - maintaining the all inputs from suppliers to production centers to customer and impacting the whole chain with improvement of the social and environmental change - should be completely regarded. In previous times, the concentration was generally on production and logistics systems from the raw material to end purchaser. Nowadays this considers environmental matters to meet the challenges of sustainability (Zailani et al., 2012). Ramudhin et al., (2009) indicates that SSCM should be evaluated together with environmental design, stock operation, production planning and checking all reverse operations, disposal procedures, energy consumption and emissions decrease.

Each key supply chain member can achieve economic advantage only when they make a long-term dedication to sustainable development. Based on the studies of three dimension, it can be said that implementation of TBL provides economic advantage (Varsei et al., 2014). As a result of increasing trend to sustainable practices, many firms have been implemented to a wide-scale adoption that they collaborate with their suppliers and customers. They improve their efficiency for operation and environment. These improvements help firms gain customer satisfaction and profitability and competitive advantage (Blome et al., 2014). The financial performance is the first priority for the economical aspect of SSCM. For the environmental performance, environmental responsibility holds minimum environmental standard regulated by government that is important. The social performance stresses social fairness, which should be considered as minimum standard of social objectivity and justice. Some of the benefits of SSCM are enhanced through corporate reputation, improved operational and financial performance (Fabbe-Costes et al., 2014). As a performance side, the pursuit of SSCM targets leads to consciousness within corporations of the environmental and social changes of their operations and forces to reduce environmental footprint. With SSCM implementation as a model it could continue and improve economic results, but tighten from environmental laws. When social and environmental friendly corporations produce any output, they are most likely chosen by stakeholders. As a result, these corporations could get a higher margin by marketing considerable quantity at a higher price to compensate any deviation expense (Ji et al., 2014).

\subsection{Supply Chain Collaboration}

SSCM practices are structured as strategic orientation, continuity, collaboration, risk management, pro-activity (for sustainability). Collaboration is evaluated as SSCM practices 
that have categorized joint development, technical integration, logistical integration and enhanced communication. Collaboration, as a SSCM practice, is linked to dynamic capabilities as the core theoretical contribution (Beske et al., 2014, p132). Dynamic capabilities are the familiarization, incorporating and re-structuring of corporations' abilities, resources and operating skills when the corporations request during the crisis or the time for determining the future rivals and demands (Kay, 2010). Creation, incorporation and restructuring of internal and external resources to compete with the rivals and even change the market dynamics are considered as dynamic capabilities by Furlan and Grandinetti (2011). Other dynamic capabilities are the skills to seek and select suitable partners for the firm, the ability to coordinate complex portfolios of relationships, and the ability to reconfigure the whole value network of the firm. Dynamic capability refers to "the capacity of an organization to purposefully create, extend, or modify its resource base" that distinguish a dynamic capability from other organizational strength and procedures (Beske, 2012).

External pressures which evaluate the impact of a dynamic collaborative capability on corporation competitiveness that helps reduce inter functional and inter organizational conflict and occurrence of a unique associated benefits. Several theories explain the dynamic capability as the significance, occurrence, and change of collaboration. In this concept "dynamic" means the corporations skills that react to changing environment. By capability definition it is "the firm's ability to integrate, build, and reconfigure internal and external competencies". Capability development process description in the literature uses terms such as "coordinate," "combine," and "integrate" (Allred et al., 2011).

Supply chain collaboration (SCC) includes two or more independent companies as partnership to achieve more surplus to maintain the operations toward common goals such as incorporating product design and lean manufacturing implementations; information sharing activities in the whole supply chain. Collaboration among supply chains can be achieved sharing information, mutual knowledge and good communication (Cao et al., 2010). Supply chain collaboration creates a trust within the supply chain members to react in the best interest of the partnership and integration to relate with their competencies, concentrating on their unique core operations to get better rivalry positions. Supply chain collaboration is a business process that chain members work as a partner to obtain mutual targets (Cao and Zhang, 2011). Another definition of supply chain collaboration is done as a corporate operation that is based on communication and relationship through the supply chain and all stakeholders and dynamic engagement of supply chain members (Liao and Kuo, 2014).

\section{HYPOTHESIS DEVELOPMENT}

Lazona (2007) indicates the collaboration as an important part of problem-solving that helps to sustainable corporations (Hoof and Thiell, 2014). Luzzini et al., (2015) analyze that commitment to sustainability guides to higher point of intra-and inter corporation collaborative capabilities which could impact performance (Luzzini et al., 2015). Collaboration is situated at firms' structural and operational level which is achieved by inter organizational level of IT\& meetings. One of their tools to increase the collaboration is information technology that could also affect their performance (Luo et al., 2015). 
Ramanathan (2014) in his research quantified supply chain collaboration for performance improvement. Collaboration has an important role to realize SSCM.

Cao et al., (2010) suggest that Supply Chain Collaboration could help reduce the risks such as conflicts, uncertainty that enhances the relationships between the stakeholders. This side of the collaboration should be considered as uncertainty reduction perspective. The other perspective is described as learning and knowledge perspective; mutual information inception that augments innovation and enlarges resources (Cao et al., 2010).It can give competitive advantage with decreasing the uncertainty in whole supply chains. This helps to gain cost advantage and also increased enhanced communication with the partners. It is seen an important key factor for SSCM performance. Collaboration helps firms to have all information all SSCM dimension through supply chain. Carter and Rogers (2008) emphasize that supply chain management collaboration enhances the competitive advantage of a supply network reduces overall cost and uncertainty (cf. Beske and Seuring, 2014). Cao and Zhang (2011) explain that the effectiveness of supply chain collaboration has positive impact on corporations' financial metrics such as market grow, profit margin on sales, return on investment, reduction of risk, cost, increasing productivity and growth that these metrics are considered as corporations' economic performance. With the collaboration knowledge sharing, refilling, and supply synchronization in a supply chain could eliminate surplus inventory, strength business strategy and quality, supply flexibility, and increase mutual innovation (Cao and Zhang, 2011). Many studies have evaluated the relationship of supply chain collaboration and firm or supply chain performance like Liao and Kuo (2014). Some authors indicate that customers and dealers are aware of the importance of collaboration in their supply chain as it automatically improves their economical results. These arguments have led us to develop the following hypothesis:

H1. There is a positive relationship between collaboration and economic performance of SSCM.

The implementation of collaboration at corporate and plant levels resolve environmental and social issues. Another study has investigated the collaboration in terms of environmental approach that impacts on sustainable supply chain performances (Chin et al., 2015). Kumar and his friends (2012) inform that due to increasing demand from environmental and social requirements, the creation of general decline is seen in disposal that comprehends water, energy, fuel usage and decreased packaging for the corporate. Vachon and Klassen (2008) explain that the implementation of collaborative activities reduce the environmental and social effects of outputs and processes (cf. Gualandris et al., 2014). Therefore the following hypothesizes are developed;

H2. There is a positive relationship between collaboration and environmental performance of SSCM.

H3. There is a positive relationship between collaboration and social performance of SSCM. 


\section{Figure 2: A framework linking Collaboration and performance of SSCM's dimensions}

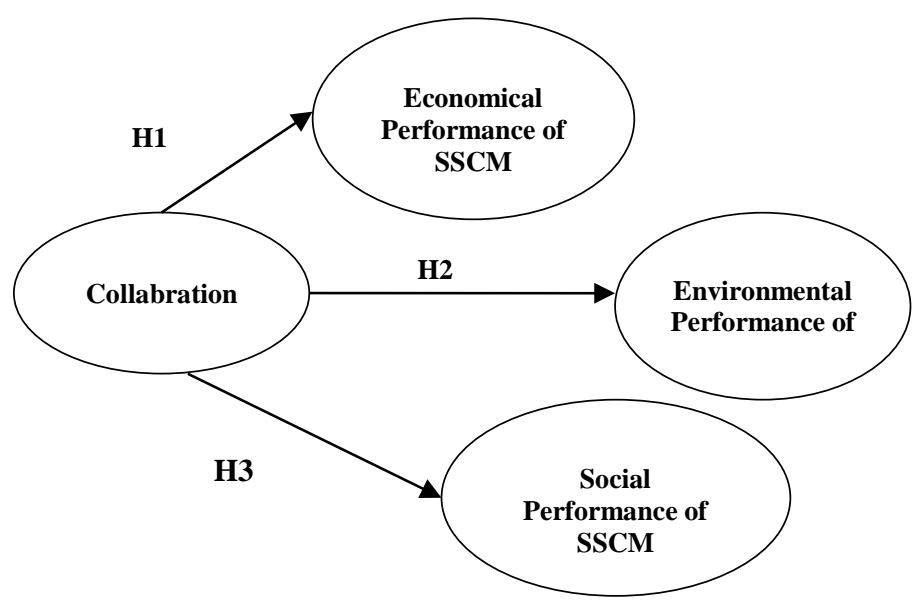

The comprehensive structure of the proposed framework is illustrated in Figure 2. It illustrates the incorporation with performance of SSCM's dimensions.

\section{DISCUSSION AND CONCLUSION}

Supply chain collaboration helps firms to gain cost optimization, good quality of product and innovation, risk minimization and better market position. Additionally it deals with the environmentally and socially issues which come from pressures like governments, customers and stakeholders. These points are all related to sustainable supply chain performances that are affected by the collaboration efforts which need to be further investigated. In recent years SSCM has been highly relevant topic in the literature. SSCM is a rising area for both researchers and application. Recently collaborative paradigm also gets the attention of these groups. Few studies explored the relationship between collaboration and firm performance. Several assessment models are available in the literature but these do not direct the SSCM performance and collaboration relation.

In this paper we try to analyze the relationship between collaboration and SSCM performance through a review of literature and practical modelling efforts. This orientation is original in the field and more empirical research is required to validate the proposed framework. Due to increasing importance of SSCM, collaboration and other practices of SSCM should be considered under the same roof as SSCM performance indicators.

\section{REFERENCES}

Ageron, B., Gunasekaran, A., Spalanzani, A. (2012), "Sustainable supply management: An empirical study", International Journal of Production Economics, Vol. 140, pp. 168-182.

Alblas, A.A., Peters, K., Wortmann, J.C. (2014), "Fuzzy sustainability incentives in new product development", International Journal of Operations \& Production Management, Vol. 34 No 4, pp. 513- 545. 
Allred, C.R., Fawcett, S.E., Wallin, C., Magnan, G.M. (2011), “A Dynamic Collaboration Capability as a Source of Competitive Advantage", Decision Sciences Journal, Vol. 42 No. 1, pp. 129-160.

Ashby, A., Leat, M., Hudson-Smith, M. (2012), "Making connections: a review of supply chain management and sustainability literature", Supply Chain Management: An International Journal, Vol. 17 No. 5, pp. 497 - 516.

Beske, P. (2012), "Dynamic capabilities and sustainable supply chain management", International Journal of Physical Distribution \& Logistics Management, Vol. 42 No. 4, pp. $372-387$.

Beske, P., Land, A., Seuring, S. (2014), "Sustainable supply chain management practices and dynamic capabilities in the food industry: A critical analysis of the literature" International Journal of Production Economics, Vol. 152, pp. 131-143.

Beske, P., Seuring, S. (2014), "Putting sustainability into supply chain management", Supply Chain Management: An International Journal, Vol. 19 No. 3, pp. $322-331$

Blome, C., Paulraj, A., Schuetz, K. (2014), "Supply chain collaboration and sustainability: a profile deviation analysis", International Journal of Operations \& Production Management, Vol. 34 No 5, pp. 639-663.

Cao, M.,, Vonderembse, M.A., Zhang, Q., Ragu-Nathan, T.S. (2010), "Supply chain collaboration: conceptualization and instrument development", International Journal of Production Research, Vol.48 No.22, pp. 6613-6635

Cao, M., Zhang, Q. (2011), "Supply chain collaboration: Impact on collaborative advantage and firm performance", Journal of Operations Management, Vol. 29, pp. 163-180

Chin, T.A., Tat,H.H.,Sulaiman, Z. (2015), “Green Supply Chain Management, Environmental Collaboration and Sustainability Performance", 12th Global Conference on Sustainable Manufacturing, Procedia CIRP 26, pp. 695699

Fabbe-Costes, N., Roussat, C., Taylor,M., Taylor, A. (2014), "Sustainable supply chains: a framework for environmental scanning practices", International Journal of Operations \& Production Management, Vol. 34 No 5 , pp. $664-694$

Furlan, A., Grandinetti, R. (2011), "Size, relationships and capabilities: A new approach to the growth of the firm", Human Systems Management, Vol. 30, pp. 195-213

Gimenez, C., Sierra, V., Rodon, J. (2012), "Sustainable operations: Their impact on the triple bottom line", International Journal of Production Economics, Vol. 140, pp. 149-159

Gupta, S., Palsule-Desai, O.D. (2011), "Sustainable supply chain management: Review and research opportunities", IIMB Management Review, Vol. 23, pp. 234-245

Gualandris, J., Golini, R., Kalchschmidt, M. (2014), "Do supply management and global sourcing matter for firm sustainability performance?", Supply Chain Management: An International Journal, Vol. 19 No. 3, pp. 258 - 274

Hassini, E., Surti, C., Searcy, C. (2012), "A literature review and a case study of sustainable supply chains with a focus on metrics", International Journal of Production Economics, Vol. 140, pp. 69-82

Hoof,B.V., Thiell,M., (2014), "Collaboration capacity for sustainable supply chain management: small and medium-sized enterprises in Mexico", Journal of Cleaner Production, Vol. 67, pp. 239-248

Hudnurkar,M., Jakhar,S., Rathod,U., (2014), "Factors affecting collaboration in supply chain: A literature Review”, Procedia-Social and Behavioral Sciences, Vol.133, pp. 189-202

Ji, G., Gunasekaran, A., Yang, G. (2014), “Constructing sustainable supply chain under double environmental medium regulations", International Journal of Production Economics, Vol. 147, pp. 211-219

Kay, N.M., (2010), "Dynamic capabilities as context: the role of decision, system and structure", Industrial and Corporate Change, Vol. 19 No.4, pp. 1205-1223

Linton, J.D., Klassen, R., Jayaraman, V. (2007), “Sustainable supply chains: An introduction”, Journal of Operations Management, Vol. 25, pp.1075-1082

Luzzini,D., B.Jones,E.,B.Jones,A.,Spina,G., (2015), “From sustainability commitment to performance: The role of intra and inter-firm collaborative capabilities in the up stream supply chain", Int. J. Production Economics, Vol. 165 , pp.51-63 
Jun Luo, Alain Yee-Loong Chong, Eric W.T. Ngai, Martin J. Liu, (2015), "Reprint of "Green Supply Chain Collaboration implementation in China: The mediating role of guanxi", Transportation Research Part E, Vol. 74, pp.37-49

Ramanathan,U., (2014), " Performance of supply chain collaboration - A simulation study", Expert Systems with Applications, Vol. 41, pp. 210-220

Shu-Hsien Liao, Fang-I Kuo (2014), "The study of relationships between the collaboration for supply chain, supply chain capabilities and firm performance:A case of the Taiwan's TFT-LCD industry", Int. J. Production Economics, Vol. 156, pp.295-304

Varsei, M., Soosay, C., Fahimnia, B., Sarkis, J. (2014), "Framing sustainability performance of supply chains with multidimensional indicators", Supply Chain Management: An International Journal, Vol. 19 No. 3, pp. $242-257$

Zacharia, Z.G., Nix, N.W., Lusch, R.F. (2011), “Capabilities that enhance outcomes of an episodic supply chain collaboration", Journal of Operations Management, Vol. 29, pp. 591-603

Zailani, S., Jeyaraman, K., Vengadasan, G., .Premkumar, R. (2012), "Sustainable supply chain management (SSCM) in Malaysia: A survey", International Journal of Production Economics, Vol. 140, pp. 330-340 